\title{
ANALISIS RASIO LIKUIDITAS, RENTABILITAS DAN SOLVABILITAS UNTUK MENILAI KINERJA KEUANGAN PT BAKRIE SUMATERA PLANTATIONS, TbK
}

\author{
${ }^{1)}$ Zeze Zakaria Hamzah, ${ }^{2)}$ Resti Nurjanah \\ ${ }^{1)}$ Dosen Program Studi Manajemen, STIE Dewantara \\ Jl. Raya Pemda Bojong Depok Baru III, Karadenan, Cibinong, Bogor, Jawa Barat 16913,Indonesia \\ Email: zeze.zakaria@dewantara.ac.id \\ ${ }^{2)}$ Alumni Program Studi Manajemen, STIE Dewantara \\ Jl. Raya Pemda Bojong Depok Baru III, Karadenan, Cibinong, Bogor, Jawa Barat 16913,Indonesia \\ Email: restinurjanah@gmail.com
}

\begin{abstract}
The purpose of this study was to determine the financial performance of PT Bakrie Sumatera Plantations, Tbk based on the Liquidity, Rentability and Solvability Ratios for the period 2012-2016. This type of research is quantitative descriptive using secondary data. This research was conducted by tracking data on the Indonesia Stock Exchange (IDX). The object of this research is the financial statements of PT Bakrie Sumatera Plantations, Tbk. The results showed that Financial Performance based on liquidity ratios, Current Ratio decreased from 1.26 to 0.09, Cash Ratio decreased from 0.040 to 0.006 and Quick Ratio decreased from 1.18 to 0.09. Based on the profitability ratio, the condition of the company is in a bad condition, because Gross Profit Margin has decreased by 0.30 to 0.25 and the Net profit margin has suffered losses from -0.38 to -0.52. Likewise based on solvency ratio, in a bad condition because Debt to Equity Ratio has increased from 0.58 to 0.92 and the value of Debt to Total Assets Ratio is higher than 1.4 to 11.27.
\end{abstract}

Keywords: Financial Performance, PT Bakrie Sumatera Plantations, Tbk.

\begin{abstract}
ABSTRAK
Tujuan penelitian ini adalah untuk mengetahui kinerja keuangan PT Bakrie Sumatera Plantations, Tbk berdasarkan Rasio Likuiditas, Rentabilitas, dan Solvabilitas periode 20122016. Jenis penelitian ini deskriptif kuantitatif dengan menggunakan data sekunder. Penelitian ini dilakukan dengan cara penelusuran data di Bursa Efek Indonesia (BEI). Objek penelitian ini adalah laporan keuangan PT Bakrie Sumatera Plantations, Tbk. Hasil penelitian menunjukkan Kinerja Keuangan berdasarkan rasio likuiditas, Current Ratio mengalami penurunan dari 1,26 menjadi 0,09, Cash Ratio mengalami penurunan dari 0,040 menjadi 0,006 dan Quick Ratio mengalami penurunan dari 1,18 menjadi 0,09. Berdasarkan rasio rentabilitas kondisi perusahaan dalam kondisi tidak baik, karena Gross Profit Margin mengalami penurunan 0,30 menjadi 0,25 dan Net profit Margin mengalami kerugian dari 0,38 menjadi $-0,52$. Begitupula berdasarkan rasio solvabilitas, dalam kondisi tidak baik karena Debt to Equity Ratio mengalami peningkatan dari 0,58 menjadi 0,92 dan nilai Debt to Total Assets Ratio semakin tinggi dari 1,4 menjadi 11,27.
\end{abstract}

Kata kunci: Kinerja Keuangan, PT Bakrie Sumatera Plantations, Tbk. 


\section{PENDAHULUAN}

Banyak perusahaan menilai kinerja perusahaannya hanya berdasarkan pada tingkat laba yang diperoleh dan mereka menganggap bahwa kinerja perusahaannya baik jika laba yang diperoleh meningkat setiap tahun. Namun tidak sepenuhnya benar karena di dalam kenyataannya ada perusahaan yang setiap tahun laba perusahaan meningkat, tetapi perusahaan tersebut mengalami kesulitan keuangan di dalam mengembangkan usaha dan melunasi utang perusahaan. Karena itu laporan keuangan menjadi faktor penting untuk menilai kinerja keuangan. Laporan keuangan juga dapat menjelaskan rasio-rasio akun neraca terhadap intern maupun ekstern perusahaan. Krisis ekonomi global berdampak terhadap kinerja keuangan PT Bakrie Sumatera Plantation, Tbk. Dalam perhitungan tahun 2012-2016 menunjukan bahwa profitabilitas mengalami penurunan. Begitu juga dengan likuidats yang mengalami penurunan.

Penelitian ini dilaksanakan dengan tujuan untuk mengetahui kinerja keuangan PT Bakrie Sumatera Plantations, Tbk berdasarkan Rasio Likuiditas, Rentabilitas, dan Solvabilitas periode 2012-2016.

\section{TINJAUAN PUSTAKA}

\subsection{Laporan Keuangan}

Menurut Ikatan Akuntan Indonesia (2009) Laporan Keuangan adalah susunan yang menyajikan posisi keuangan dan kinerja keuangan dalam sebuah entitas. Kinerja perusahaan merupakan sesuatu yang dihasilkan oleh perusahaaan dalam periode tertentu yang berhubungan dengan tujuan organisasi. Kinerja ini dapat memperlihatkan tingkat kesehatan perusahaan agar dapat melihat apakah suatu keuangan dalam suatu perusahaan itu dalam keadaan sehat atau tidak.
Teknik analisis yang biasa digunakan dalam analisa laporan keuangan adalah sebagai berikut:

1. Analisis perbandingan laporan keuangan adalah metode dan teknik analisa dengan cara membandingkan laporan keuangan untuk dua periode atau lebih dengan menunjukkan:

1. Data absolute atau jumlah dalam rupiah.

2. Kenaikan atau penurunan dalam jumlah rupiah.

3. Kenaikan atau penurunan dalam prosentase.

4. Perbandingan yang dinyatakan dalam ratio.

5. Presentase dari total.

2. Analisis trend atau tendensi merupakan analisis laporan keuangan yang biasanya dinyatakan dalam persentase tertentu. Data keuangan yang digunakan untuk mengadakan analisis trend dengan persentase adalah data yang paling awal. Kemudian, data tersebut dibandingkan dengan data selanjutnya. Artinya data paling awal dianggap sebagai tahun dasar sebagai awal perhitungan. (Kasmir,2008:82).

3. Analisis persentase per komponen merupakan teknik analisis laporan keuangan dengan menganalisis komponen-komponen yang ada dalam laporan keuangan. Tujuan analisis per komponen adalah untuk mengetahui halhal antara lain (Kasmir, 2008:91).

Tujuan analisis per komponen adalah untuk mengetahui hal-hal antara lain (Kasmir, 2008:91).

1. Persentase investasi terhadap masingmasing aktiva atau terhadap passiva.

2. Untuk mengetahui struktur permodalan.

3. Untuk mengetahui komposisi biaya terhadap penjualan.

4. Analisis sumber dan penggunaan modal kerja merupakan suatu analisis yang 
berhubungan dengan sumber-sumber penggunaan dana yang berkaitan dengan modal kerja perusahaan. Artinya dari mana saja perusahaan memperoleh dana guna membiayai kegiatannya. (Kasmir, 2008:248).

5. Analisis sumber dan penggunanaan kas (cash flow statement analysis) adalah analisa untuk mengetahui sebab-sebab berubahnya jumlah uang kas selama periode tertentu.

6. Analisis rasio adalah suatu metode analisa untuk mengetahui hubungan dari pos-pos tertentu dalam neraca atau laporan laba rugi secara individual atau kombinasi dari kedua laporan tersebut.

Analisis rasio keuangan dapat dilakukan dengan 2 metode analisis, yaitu:

1. Analisis vertikal merupakan analisis yang dilakukan terhadap satu periode laporan keuangan saja. Analisis dilakukan antara pos-pos yang ada, dalam satu periode. Informasi yang diperoleh hanya untuk satu periode saja dan tidak diketahui perkembangan dari periode ke periode.

2. Analisis horizontal merupakan analisis yang dilakukan dengan membandingkan laporan keuangan untuk beberapa periode. Dari hasil analsis ini akan terlihat perkembangan perusahaan dari periode yang satu ke periode yang lain.

Tingkat kesehatan perusahaan diperlukan untuk melihat apakah suatu keuangan dalam suatu perusahaan itu dalam keadaan sehat atau tidak. Hal ini dapat dilakukan dengan membandingkan antara dua elemen yang ada atau disebut dengan rasio. Dengan rasio itu kita dapat mengetahui tingkat likuiditas, rentabilitas dan solvabilitas suatu perusahaan dalam suatu periode tertentu. Peningkatan kinerja harus selalu dikaitkan dengan penerapan prinsip efisiensi. Efisiensi artinya menampilkan kinerja yang memuaskan suatu sistem bekerja sehingga hasilnya digunakan sebagai sarana, daya dan dana yang dialokasikan untuk menyelenggarakannya (Siagian, 2000:50).

Tingkat kesehatan perusahaan diperlukan untuk mengetahui kondisi keuangan perusahaan tersebut baik atau tidak. Hal ini dapat dilakukan dengan membandingkan antara rasio tahun sebelumnya dengan rasio pada saat ini. Perbandingan tersebut dapat digunakan oleh pihak yang berkepentingan untuk mengetahui tingkat likuiditas, solvabilitas, dan rentabilitas perusahaan pada saat tertentu. Pengukuran kinerja adalah penentuan secara periodik tampilan perusahaan yang berupa kegiatan operasional, struktur organisasi, dan karyawan yang berdasarkan sasaran, standar dan kriteria yang telah ditetapkan sebelummya. Pengukuran kinerja adalah kualifikasi dan efisiensi perusahaan atau segmen atau keefektifan dalam pengoperasian bisnis selama periode akuntansi. Pengertian kinerja adalah suatu usaha formal yang dilaksanakan perusahaan untuk mengevaluasi efisien dan efektivitas dari aktivitas perusahaan yang telah dilaksanakan pada periode waktu tertentu (Bayuristyawan, 2013).

Cara untuk mengukur tingkat kesehatan tersebut dengan menggunakan analisis rasio keuangan. Seperti yang disampaikan (Hery, 2015:161) bahwa Rasio keuangan merupakan suatu perhitungan rasio dengan menggunakan laporan keuangan yang berfungsi sebagai alat ukur dalam menilai kondisi keuangan dan kinerja perusahaan

Jenis-jenis rasio keuangan:

1. Rasio likuiditas adalah rasio yang menunjukkan hubungan antara kas dan aset lancar perusahaan lainnya dengan kewajiban lancarnya (Brigham dan Houston, 2011) diantaranya dari rasio lancer, rasio kas dan rasio cepat.

Rasio lancar merupakan rasio yang digunakan untuk mengukur kemampuan 
perusahaan dalam membayar kewajiban jangka pendeknya dengan menggunakan aktiva lancar yangdimiliki. Rasio Kas merupakan rasio yang digunakan untuk mengukur kemampuan perusahaan dalam membayar kewajiban jangka pendek dengan kas yang tersedia dan yang disimpan di Bank. Rasio Cepat merupakan rasio yang digunakan untuk mengukur kemampuan perusahaan dalam membayar kewajiban jangka pendeknya dengan menggunakan aktiva yang lebih likuid.

2. Rasio rentabilitas adalah kemampuan perusahaan untuk menghasilkan laba selama periode tertentu Munawir (2010) diantaranya Margin laba kotor dan margin laba bersih. Rasio margin laba kotor merupakan perbandingan antar penjualan bersih dikurangi dengan harga pokok penjualan dibandingkan dengan tingkat penjualan dan Margin laba bersih merupakan rasio yang digunakan untuk mengukur laba bersih sesudah pajak lalu dibandingkan dengan volume penjualan.

3. Rasio solvabilitas untuk mengukur sejauh mana aset perusahaan dibiayai dengan utang (Hery, 2015) diantaranra Rasio Hutang terhadap Total Aktiva dan Rasio Hutang terhadap Ekuitas. Rasio ini disebut juga sebagai rasio yang melihat perbandingan utang perusahaan, yaitu diperoleh dari perbandingan total utang dibagi dengan asset dan Rasio utang terhadap modal yang digunakan untuk mengukur besarnya proporsi hutang dengan modal.

\subsection{Kerangka Pemikiran}

Dalam memenuhi kebutuhan modal kerja harus mengadakan keseimbangan antara tujuan likuiditas dan rentabilitas dengan mengadakan kombinasi yang optimal antara pemenuhan kredit jangka panjang dengan jangka pendek, yang dalam literatur pembelanjaan disebutkan sebagai masalah optimum modal (Riyanto, 2001:193)

Rasio likuiditas terdiri dari current ratio, cash ratio, dan quick ratio. Current ratio dikatakan sehat jika aktiva lancar lebih besar dari utang lancar. Cash ratio dikatakan sehat jika hasil rasio menunjukkan 1:1 atau 100\% atau semakin besar perbandingan kas dengan utang maka akan semakin baik. Quick ratio dikatakan sehat jika jumlah rasio semakin besar, angka rasio tidak harus $100 \%$ atau 1:1. Walaupun rasio tidak mencapai $100 \%$ tapi mendekati $100 \%$ juga sudah dikatakan sehat.

1. Rasio rentabilitas terdiri dari gross profit margin dan net profit margin. Gross profit margin dikatakan sehat jika jumlah rasionya semakin besar, mampu menghasilkan laba yang dapat menutupi biaya-biaya tetap atau biaya operasi lainnya. Net profit margin dikatakan sehat jika semakin tinggi jumlah rasionya, mampu menghasilkan laba yang tinggi pada tingkat penjualan tertentu.

2. Rasio solvabilitas terdiri dari total debt to asset ratio dan total debt to equity ratio. Total debt to asset ratio dikatakan sehat/aman jika jumlah rasionya semakin kecil (solvable), porsi hutang terhadap aktiva harus lebih kecil. Total debt to equity ratio dikatakan sehat/aman jika jumlah rasionya semakin kecil, maksudnya yaitu semakin kecil porsi hutang terhadap modal.

\section{METODE PENELITIAN}

\subsection{Jenis Penelitian}

Jenis penelitian ini yaitu deskriptif kuantitatif yang merupakan jenis penelitian untuk menjelaskan serta menyajikan hasil penelitian tentang kinerja keuangan perusahaan dengan menggunakan rasio-rasio keuangan yaitu rasio likuiditas, rasio 
rentabilitas, dan rasio solvabilitas pada PT Bakrie Sumatera Plantations, Tbk.

\subsection{Variabel Penelitian}

Dalam penelitian ini variabelnya yaitu Kinerja Keuangan.

\subsection{Lokasi dan Waktu Penelitian}

Lokasi penelitian ini dilakukan dengan menelusuri data di Bursa Efek Indonesia yang sudah dipublikasi di www.idx.com dan laporan keuangan PT Bakrie Sumatera Plantations, Tbk. Waktu penelitian dimulai pada bulan November 2017 sampai dengan Februari 2018.

\subsection{Obyek Penelitian}

Dalam penelitian ini yang akan menjadi obyek penelitian adalah Laporan Keuangan pada PT Bakrie Sumatera Plantations, Tbk.

\subsection{Populasi dan Sampel}

Populasi yang menjadi bahan penelitian ini adalah Laporan Keuangan pada PT Bakrie Sumatera Plantations, Tbk dari tahun 2012 sampai dengan tahun 2016.

\subsection{Teknik Pengumpulan Data}

Dalam penelitian ini akan digunakan teknik pengumpulan datanyasebagai berikut:

a. Observasi yaitu melakukan pengamatan secara langsung pada PT Bank Syariah Mandiri.

b. Dokumentasi yaitu suatu teknik pengumpulan data dengan membuat salinan atau mengadakan arsip-arsip dan catatan-catatan perusahaan yang ada mengenai sejarah singkat perusahaan atau gambaran umum perusahaan, neraca dari tahun 2012-2016.

\subsection{Teknik Analisis Data}

Metode analisis data yang digunakan dalam penelitian ini adalah metode deskriptif kuantitatif, yaitu analisis terhadap data yang berbentuk angka, menyusun, mengelompokkan, dan menghitung dengan rumus yang relevan sehingga diperoleh gambaran yang jelas tentang kinerja keuangan.

\section{Kinerja Keuangan berdasarkan Rasio Likuiditas}

Rasio likuiditas adalah rasio yang digunakan untuk mengukur kemampuan perusahaan dalam memenuhi kewajiban financial jangka pendek berupa utang-utang jangka pendek.

a. Rasio Lancar (Current Ratio)

$$
\text { Current Ratio }=\quad \begin{aligned}
& \text { Aktiva Lancar } \\
& \text { Utang Lancar }
\end{aligned}
$$

b. Rasio Kas (Cash Ratio)

Quick Ratio $=\frac{\text { Aktiva Lancar }- \text { Persediaan }}{\text { Utang Lancar }}$

c. Rasio Cepat (Quick Ratio)

$$
\text { Cash Ratio }=\frac{\text { Kas }+ \text { Setara Kas }}{\text { Utang Lancar }}
$$

\section{Kinerja Keuangan berdasarkan Rasio Rentabilitas}

Rasio ini disebut juga sebagai rasio profitabilitas yaitu rasio yang digunakan untuk mengukur kemampuan perusahaan dalam memperoleh laba atau keuntungan.

a. Gross Profit Margin (Margin Laba Kotor)

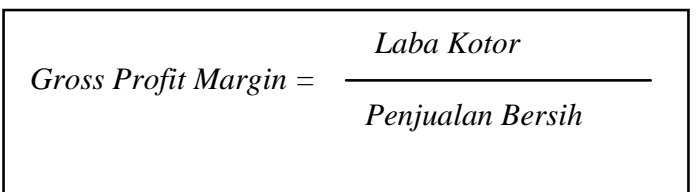

b. Net Profit Margin (Margin Laba Bersih) 


$$
\text { Net Profit Margin }=\frac{\text { Laba Setelah Pajak }}{\text { Penjualan Bersih }}
$$

\section{Kinerja Keuangan berdasarkan Rasio Solvabilitas}

Rasio yang digunakan untuk mengukur sampai seberapa jauh aktiva perusahaan dibiayai oleh hutang.

a. Total Debt to Asset Ratio (Rasio Hutang terhadap Total Aktiva)

Total Debt To Asset Ratio $=\frac{\text { Total Utang }}{\text { Total Aktiva }}$

b. Total Debt to Equity Ratio (Rasio Hutang terhadap Ekuitas)

Total Debt To Equity Ratio $=\frac{\text { Total Utang }}{\begin{array}{c}\text { Ekuitas Pemegang } \\ \text { Saham }\end{array}}$

\section{HASIL DAN PEMBAHASAN}

\subsection{Kinerja Keungan berdasarakan} rasio likuiditas

a. Current Ratio (Rasio Lancar)

Berikut tabel rasio lancar (current ratio) untuk tahun 2012-2016:

Tabel 4.1 Current Ratio Tahun 2012 Tahun 2016

\begin{tabular}{|r|c|c|c|c|}
\hline Tahu & $\begin{array}{c}\text { Aktiva Lancar } \\
\text { (Rp) }\end{array}$ & $\begin{array}{c}\text { Utang Lancar } \\
(\mathrm{Rp}) \\
(\mathrm{a})\end{array}$ & $\begin{array}{c}\text { Current Ratio } \\
\text { (c)=(a):(b) }\end{array}$ & $\begin{array}{r}\text { Perubahan } \\
\text { Rasio } \\
\text { Cepat }\end{array}$ \\
\hline 2012 & 3.788 .485 .702 & 3.001 .002 .905 & 1,26 & - \\
\hline 2013 & 3.459 .892 .276 & 6.359 .394 .322 & 0,54 & $-0,72$ \\
\hline 2014 & 2.597 .496 .750 & 7.699 .735 .962 & 0,34 & $-0,20$ \\
\hline 2015 & 1.473 .246 .391 & 7.965 .667 .450 & 0,18 & $-0,16$ \\
\hline 2016 & 1.014 .926 .396 & 10.292 .576 .380 & 0,09 & $-0,09$ \\
\hline
\end{tabular}

Berdasarkan tabel 4.1 Current ratio pada tahun 2012 sebanyak 1,26 kali. Artinya setiap 1 rupiah utang lancar dijamin oleh 1,26 aktiva lancar. Pada tahun 2013 current ratio sebanyak 0,54 kali. Jadi, setiap 1 rupiah utang lancar dijamin oleh 0,54 aktiva lancar. Pada tahun 2014 sebanyak 0,34 kali, yang berarti setiap 1 rupiah utang lancar dijamin oleh 0,34 aktiva lancar. Pada tahun 2015 sebanyak 0,18 kali, yang berarti setiap 1 rupiah utang lancar dijamin oleh 0,18 aktiva lancar. Dan tahun 2016 sebanyak 0,09 kali, yang berarti setiap 1 rupiah utang lancar dijamin oleh 0,09 aktiva lancar.

Rasio lancar PT Bakrie Sumatera Plantations, Tbk mengalami penurunan pada tahun 2012 sampai dengan tahun 2016. Yang artinya PT Bakrie Sumatera Plantations, Tbk dikatakan perusahaan yang tidak sehat karena memiliki aktiva lancar yang lebih kecil dibandingkan dengan utang lancar. Walaupun pada tahun 2012 aktiva lancar lebih besar dibandingkan dengan utang lancar.

b. Cash Ratio (Rasio Kas)

Berikut tabel rasio kas (cash ratio) untuk tahun 2012-2016:

Tabel 4.2 Cash Ratio Tahun 2012 - Tahun 2016

\begin{tabular}{|c|c|c|c|c|}
\hline Tahun & $\begin{array}{c}\text { Kas+Setara } \\
\text { Kas } \\
(\mathrm{Rp}) \\
(\mathrm{a})\end{array}$ & $\begin{array}{c}\text { Utang Lancar } \\
(\mathrm{Rp}) \\
(\mathrm{b})\end{array}$ & $\begin{array}{c}\text { Cash Ratio } \\
(\mathrm{c})=(\mathrm{a}):(\mathrm{b})\end{array}$ & $\begin{array}{c}\text { Perubahan } \\
\text { Cash } \\
\text { Ratio }\end{array}$ \\
\hline 2012 & 120.765 .649 & 3.001 .002 .905 & 0,040 & - \\
\hline 2013 & 117.017 .409 & 6.359 .394 .322 & 0,018 & $-0,022$ \\
\hline 2014 & 55.595 .947 & 7.699 .735 .962 & 0,007 & $-0,011$ \\
\hline 2015 & 43.967 .471 & 7.965 .667 .450 & 0,005 & $-0,002$ \\
\hline 2016 & 60.760 .184 & 10.292 .576 .380 & 0,006 & 0,001 \\
\hline
\end{tabular}

Berdasarkan tabel 4.2 Cash ratio PT Bakrie Sumatera Plantations, Tbk pada tahun 2012 sebesar 0,040. Pada tahun 2013 sebesar 0,018 mengalami penurunan sebesar 0,022 , artinya kemampuan kas perusahaan membiayai utangnya menurun. Pada tahun 2014 sebesar 0,007 mengalami penurunan sebesar 0,011, artinya kemampuan kas perusahaan membiayai utangnya menurun. Pada tahun 2015 sebesar 0,005 mengalami penurunan sebesar 0,002, artinya kemampuan 
kas perusahaan membiayai utangnya menurun.

Walaupun mengalami kenaikan pada tahun 2016, namun rasio kas PT Bakrie Sumatera Plantations, Tbk mengalami penurunan pada tahun 2012 sampai dengan tahun 2015. Yang artinya PT Bakrie Sumatera Plantations, Tbk dikatakan perusahaan yang tidak sehat karena hasil rasio tidak menunjukkan 1:1.

\section{c. Quick Ratio (Rasio Cepat)}

Berikut tabel rasio cepat (quick ratio) untuk tahun 2012-2016

Tabel 4.3 Quick Ratio Tahun 2012 Tahun 2016

\begin{tabular}{|c|c|c|c|c|c|}
\hline Tahun & $\begin{array}{r}\text { Aktiva Lancar } \\
(\mathrm{Rp}) \\
(\mathrm{a})\end{array}$ & $\begin{array}{c}\text { Persediaan } \\
(\mathrm{Rp}) \\
(\mathrm{b})\end{array}$ & $\begin{array}{c}\text { Utang Lancar } \\
(\mathrm{Rp}) \\
(\mathrm{c})\end{array}$ & $\begin{array}{r}\text { Quick Ratio } \\
(\mathrm{d})=(\mathrm{a}-\mathrm{b}):(\mathrm{c})\end{array}$ & $\begin{array}{r}\text { Perubahan } \\
\text { Quick } \\
\text { Ratio }\end{array}$ \\
\hline 2012 & 3.788 .485 .702 & 240.455 .330 & 3.001 .002 .905 & 1,18 & - \\
\hline 2013 & 3.459 .892 .276 & 163.506 .574 & 6.359 .394 .322 & 0,52 & $-0,66$ \\
\hline 2014 & 2.597 .496 .750 & 134.447 .132 & 7.699 .735 .962 & 0,32 & $-0,20$ \\
\hline 2015 & 1.473 .246 .391 & 146.882 .913 & 7.965 .667 .450 & 0,17 & $-0,15$ \\
\hline 2016 & 1.014 .926 .396 & 98.236 .438 & 10.292 .576 .380 & 0,09 & $-0,08$ \\
\hline
\end{tabular}

Berdasarkan tabel 4.3 Quick ratio PT Bakrie Sumatera Plantations, Tbk pada tahun 2012 sebesar 1,18. Pada tahun 2013 sebesar 0,52 mengalami penurunan sebesar 0,66, artinya kemampuan perusahaan menutup utang lancarnya menggunakan aktiva lancar selain persediaan semakin menurun. Pada tahun 2014 sebesar 0,32 mengalami penurunan sebesar 0,2 , artinya kemampuan perusahaan menutup utang lancarnya menggunakan aktiva lancar selain persediaan semakin menurun. Pada tahun 2015 sebesar 0,17 mengalami penurunan sebesar 0,15 , artinya kemampuan perusahaan menutup utang lancarnya menggunakan aktiva lancar selain persediaan semakin menurun. Pada tahun 2016 sebesar 0,09 mengalami penurunan sebesar 0,08 , artinya kemampuan perusahaan menutup utang lancarnya menggunakan aktiva lancar selain persediaan semakin menurun.

Berdasarkan data di atas, dapat dilihat bahwa current ratio pada PT Bakrie Sumatera Plantation, Tbk mengalami penurunan dari tahun 2013-2016 walaupun pada tahun 2012 PT Bakrie berada di posisi aman, cash ratio pada PT Bakrie Sumatera Plantations dari periode tahun 2012-2016 mengalami penurunan dan quick ratio pada PT Bakrie Sumatera Plantations juga menurun dari tahun 2012-2016. Jadi, jika dinilai dari rasio likuiditasnya, kinerja keuangan PT Bakrie Sumatera Plantations, Tbk periode 2012-2016 dalam kondisi tidak baik.

\subsection{Kinerja Keuangan Berdasarkan Rasio Rentabilitas \\ a. Gross Profit Margin (Margin Laba Kotor}

Berikut tabel margin laba kotor (gross profit margin) untuk tahun 2012-2016.

Tabel 4.4 Gross Profit Margin Tahun 2012 - Tahun 2016

\begin{tabular}{|c|c|c|c|c|}
\hline Tahun & $\begin{array}{c}\text { Laba Kotor } \\
(\mathrm{Rp}) \\
(\mathrm{a})\end{array}$ & $\begin{array}{c}\text { Penjualan } \\
\text { Bersih } \\
(\mathrm{Rp}) \\
(\mathrm{b})\end{array}$ & $\begin{array}{r}\text { Gross Profit } \\
\text { Margin } \\
(\mathrm{c})=(\mathrm{a}):(\mathrm{b})\end{array}$ & $\begin{array}{r}\text { Perubaha } \\
\mathrm{n} \\
\text { Marg } \\
\text { in } \\
\text { Laba } \\
\text { Kotor }\end{array}$ \\
\hline 2012 & 748.665 .791 & 2.485 .429 .887 & 0,30 & - \\
\hline 2013 & 590.886 .789 & 2.076 .486 .069 & 0,28 & $-0,02$ \\
\hline 2014 & 730.649 .687 & 2.636 .703 .408 & 0,27 & $-0,01$ \\
\hline 2015 & 513.615 .694 & 2.021 .646 .748 & 0,25 & $-0,02$ \\
\hline 2016 & 475.953 .931 & 1.565 .243 .696 & 0,30 & 0,05 \\
\hline
\end{tabular}

Berdasarkan tabel 4.4 nilai Gross Profit Margin yang diperoleh PT Bakrie Sumatera Plantations, Tbk pada tahun 2012 sebesar 0,30. Pada tahun 2013 Gross Profit Margin menurun menjadi 0,28 yang artinya rasio menurun sebesar 2\%. Nilai Gross Profit Margin pada tahun 2014 menurun menjadi 0,27 yang artinya rasio menurun sebesar $1 \%$. Pada tahun 2015 Gross Profit Margin 
mengalami penurunan menjadi 0,25 yang artinya rasio menurun sebesar $2 \%$. Dan pada tahun 2015 mengalami kenaikan sebesar 5\%.

Margin Laba Kotor PT Bakrie Sumatera Plantations, Tbk mengalami penurunan pada tahun 2012 sampai dengan tahun 2015 dan mengalami kenaikan kembali pada tahun 2016. Yang artinya PT Bakrie Sumatera Plantations, Tbk dikatakan perusahaan yang kurang sehat karena jumlah rasio Gross Profit Margin dari periode tahun 2012-2015 mengalami penurunan, walaupun mengalami kenaikan kembali pada tahun 2016.

\section{b. Net Profit Margin (Margin Laba Bersih)}

Berikut tabel margin laba bersih (net profit margin) untuk tahun 2012-2016:

Tabel 4.5 Net Profit Margin Tahun 2012 Tahun 2016

\begin{tabular}{|c|c|c|c|c|}
\hline Tahun & $\begin{array}{r}\text { Laba Setelah } \\
\text { Pajak (Rp) } \\
\text { (a) }\end{array}$ & $\begin{array}{c}\text { Penjualan } \\
\text { Bersih(Rp) } \\
\text { (b) }\end{array}$ & $\begin{array}{r}\text { Net Profit } \\
\text { Margin } \\
\text { (c)=(a):(b) }\end{array}$ & $\begin{array}{r}\text { Perubahan } \\
\text { Margin } \\
\text { Laba } \\
\text { Bersih }\end{array}$ \\
\hline $\mathbf{2 0 1 2}$ & -944.848 .621 & 2.485 .429 .887 & $-0,38$ & - \\
\hline 2013 & -2.566 .042 .503 & 2.076 .486 .069 & $-1,24$ & $-0,86$ \\
\hline 2014 & -510.002 .416 & 2.636 .703 .408 & $-0,19$ & 1,05 \\
\hline 2015 & -1.057 .852 .553 & 2.021 .646 .748 & $-0,52$ & $-0,33$ \\
\hline 2016 & -606.401 .706 & 1.565 .243 .696 & $-0,38$ & 0,14 \\
\hline
\end{tabular}

Berdasarkan tabel 4.5 Net Profit Margin PT Bakrie Sumatera Plantations, Tbk mengalami kerugian yaitu pada tahun 2012 sebesar 0,38 dan pada tahun 2013 kerugian naik menjadi 1,24. Pada tahun 2014 kerugian turun menjadi 0,19. Pada tahun 2015 kerugian kembali mengalami kenaikan menjadi 0,52 dan pada tahun 2016 jumlah kerugian mengalami penurunan menjadi 0,38

Berdasarkan data di atas, dapat dilihat bahwa nilai rasio gross profit margin pada PT Bakrie Sumatera Plantations, Tbk mengalami penurunan pada 2012 sampai dengan tahun 2015 walaupun terjadi kenaikan nilai rasio pada tahun 2016 dan net profit margin pada PT Bakrie Sumatera Plantations, Tbk mengalami kerugian/penurunan periode tahun 2012-2016 karena nilai rasio setiap tahunnya memiliki nilai negatif. Jadi, jika dinilai dari rasio rentabilitasnya, kinerja keuangan PT Bakrie Sumatera Plantations, Tbk dalam kondisi tidak baik.

\subsection{Kinerja Keuangan Berdasarkan Rasio Solvabilitas}

a. Total Debt to Asset Ratio (Rasio Hutang terhadap Total Aktiva)

Berikut tabel rasio hutang terhadap total aktiva (total debt to asset ratio) untuk tahun 2012-2016:

Tabel 4.6 Total Debt To Asset Ratio Tahun 2012 - Tahun 2016

\begin{tabular}{|r|r|r|r|r|}
\hline Tahun & $\begin{array}{r}\text { Total Utang } \\
(\mathbf{R p}) \\
(\mathbf{a})\end{array}$ & $\begin{array}{r}\text { Total Aktiva (Rp) } \\
(\mathbf{b})\end{array}$ & $\begin{array}{r}\text { Total Debt To } \\
\text { Asset Ratio } \\
(\mathrm{c})=(\mathrm{a}):(\mathbf{b})\end{array}$ & $\begin{array}{r}\text { Perubahan } \\
\text { Total Debt } \\
\text { To Asset } \\
\text { Ratio }\end{array}$ \\
\hline $\mathbf{2 0 1 2}$ & 11.068 .929 .244 & 18.983 .332 .052 & 0,58 & - \\
\hline $\mathbf{2 0 1 3}$ & 13.148 .137 .788 & 18.015 .337 .232 & 0,73 & 0,15 \\
\hline $\mathbf{2 0 1 4}$ & 13.287 .430 .491 & 17.441 .633 .398 & 0,76 & 0,03 \\
\hline $\mathbf{2 0 1 5}$ & 13.569 .811 .257 & 16.926 .616 .869 & 0,89 & 0,13 \\
\hline $\mathbf{2 0 1 6}$ & 13.502 .629 .178 & 14.700 .318 .360 & 0,92 & 0,03 \\
\hline
\end{tabular}

Berdasarkan tabel 4.6 nilai rasio Total Debt To Asset Ratio PT Bakrie Sumatera Plantations, Tbk pada tahun 2012 sebesar 0,58, terjadi kenaikan selama 4 tahun mendatang. Pada tahun 2013 Total Debt To Asset Ratio mengalami kenaikan menjadi 0,73. Pada tahun 2014 naik menjadi 0,76. Pada tahun 2015 naik menjadi 0,89 dan pada tahun 2016 naik menjadi 0,92.

Rasio Hutang terhadap Total Aktiva PT Bakrie Sumatera Plantations, Tbk mengalami kenaikan pada tahun 2012 sampai dengan tahun 2016. Yang artinya PT Bakrie Sumatera Plantations, Tbk dikatakan perusahaan yang tidak sehat karena hasil 
rasio dari tahun 2012-2016 semakin naik atau meningkat.

\section{b. Total Debt to Equity Ratio (Rasio Utang} Terhadap Ekuitas)

Berikut tabel rasio hutang terhadap ekuitas (total debt to equity ratio) untuk tahun 20122016:

Tabel 4.7 Total Debt To Equity Ratio Tahun 2012 - Tahun 2016

\begin{tabular}{|c|c|c|c|c|}
\hline Tahun & $\begin{array}{c}\text { Total Utang (Rp) } \\
\text { (a) }\end{array}$ & $\begin{array}{l}\text { Ekuitas Pemegang } \\
\text { Saham (Rp) } \\
\text { (b) }\end{array}$ & $\begin{array}{c}\text { Total Debt To } \\
\text { Equity } \\
\text { Ratio } \\
\text { (c)=(a) } \text { (b) }\end{array}$ & $\begin{array}{c}\text { Perubahan } \\
\text { Total Debt } \\
\text { To Equity } \\
\text { Ratio }\end{array}$ \\
\hline 2012 & 11.068 .929 .244 & 7.914 .402 .808 & 1,4 & - \\
\hline 2013 & 13.148 .137 .788 & 4.867.199.444 & 2,7 & 1,3 \\
\hline 2014 & 13.287 .430 .491 & 4.154 .202 .907 & 3,2 & 0,5 \\
\hline 2015 & 13.569.811.257 & 3.356.805.612 & 4,04 & 0,84 \\
\hline 2016 & 13.502 .629 .178 & 1.197.689.182 & 11,27 & 7,23 \\
\hline
\end{tabular}

Berdasarkan tabel 4.7 nilai rasio Total Debt To Equity Ratio PT Bakrie Sumatera Plantations, Tbk pada tahun 2012 sebesar 1,4. Pada tahun 2013 Total Debt To Asset Ratio mengalami kenaikan menjadi 2,7. Pada tahun 2014 mengalami kenaikan menjadi 3,2. Pada tahun 2015 naik menjadi 4,04 dan pada tahun 2016 terjadi kenaikan yang cukup tinggi menjadi 11,27.

Berdasarkan data di atas, dapat dilihat bahwa nilai total debt to asset ratio pada PT Bakrie Sumatera Plantations, Tbk pada periode tahun 2012-2016 semakin meningkat dan nilai total debt to equity ratio pada PT Bakrie Sumatera Plantations, Tbk pada periode tahun 2012-2016 semakin tinggi atau meningkat. Jadi, jika dinilai dari rasio solvabilitasnya, kinerja keuangan pada PT Bakrie Sumatera Plantations, Tbk dalam kondisi tidak baik.

\section{KESIMPULAN DAN SARAN}

\subsection{Kesimpulan}

Kesimpulan dari penelitian ini adalah sebagai berikut:

1. Jika dilihat dari rasio likuiditasnya, kinerja keuangan PT Bakrie Sumatera Plantations, Tbk periode 2012-2016 dalam kondisi tidak baik. Hal tersebut dapat dilihat bahwa current ratio pada PT Bakrie Sumatera Plantation, Tbk mengalami penurunan dari tahun 2012-2016 dari 1,26 menjadi 0,09, cash ratio pada PT Bakrie Sumatera Plantations dari periode tahun 2012-2016 mengalami penurunan dari 0,040 menjadi 0,006 dan quick ratio pada PT Bakrie Sumatera Plantations juga menurun periode tahun 2012-2016 dari 1,18 menjadi 0,09

2. Jika dilihat dari rasio rentabilitasnya, kinerja keuangan PT Bakrie Sumatera Plantations, Tbk dalam kondisi tidak baik. Hal tersebut dapat dilihat bahwa nilai rasio gross profit margin pada PT Bakrie Sumatera Plantations, Tbk mengalami penurunan pada 2012 sampai dengan tahun 2015 dari 0,30 menjadi 0,25, walaupun terjadi kenaikan nilai rasio pada tahun 2016 dan net profit margin pada PT Bakrie Sumatera Plantations, Tbk mengalami kerugian/penurunan periode tahun 2012-2016 dari -0,38 menjadi -0,52 karena nilai rasio setiap tahunnya memiliki nilai negatif.

3. Jika dilihat dari rasio solvabilitasnya, kinerja keuangan pada PT Bakrie Sumatera Plantations, Tbk dalam kondisi tidak baik. Hal tersebut dapat dilihat bahwa nilai total debt to asset ratio pada PT Bakrie Sumatera Plantations, Tbk pada periode tahun 2012-2016 semakin meningkat dari 0,58 menjadi 0,92 dan nilai total debt to equity ratio pada $\mathrm{PT}$ Bakrie Sumatera Plantations, Tbk pada 
periode tahun 2012-2016 semakin tinggi atau meningkat dari 1,4 menjadi 11,27.

\subsection{Saran}

Berdasarkan hasil penelitian, pembahasan dan kesimpulan diatas, makadiajukan beberapa saran sebagai berikut:

1. Rasio Likuiditas pada PT Bakrie Sumatera Plantation dalam kondisi tidak baik, maka disarankan untuk menambah modal kerja perusahaan yang bukan bersumber dari utang sehingga rasio likuiditas dapat ditingkatkan.

2. Rasio Rentabilitas pada PT Bakrie Sumatera Plantation dalam kondisi tidak baik, maka disarankan untuk lebih mengontrol pengeluaran untuk biaya tetap atau biaya operasi lainnya agar perusahaan dapat menikmati laba perusahaan.

3. Rasio Solvabilitas pada PT Bakrie Sumatera Plantation dalam kondisi tidak baik, maka disarankan untuk menambah modal saham dalam rangka menutupi jumlah utang yang terlalu tinggi

\section{DAFTAR PUSTAKA}

Baridwan, Zaki. Intermediate Accounting. Edisi 8. Yogyakarta: BPFE. 2004.

Brigham dan Houston. Dasar-dasar Manajemen Keuangan. Edisi Sebelas. Jakarta: Salemba Empat. 2011.

Dewi, Sevika Renita. Analisa Perbandingan Kinerja Keuangan Beberapa Perusahaan Sebelum dan Sesudah Akuisisi (Studi Pada Perusahaan Pengakuisisi yang Terdaftar di BEI Periode 2003-2013). Jurnal Ekonomi dan Bisnis. Universitas Dian Nuswantoro. 2015.

Hanafi, Mamduh. Analisis Laporan Keuangan. Edisi Kedua. Yogyakarta: UPP AMP YKPN. 2005.
Harahap, Sofyan. Analisis Kritis Atas Laporan Keuangan. Edisi Kelima. Jakarta: PT Raja Grafindo Persada. 2006.

Hery. Analisis Laporan Keuangan Pendekatan Rasio Keuangan. Yogyakarta: CAPS. 2015.

Ikatan Akuntasi Indonesia. Standar Akuntansi Keuangan. Jakarta: Salemba Empat. 2009.

Irham, Fahmi. Analisa Kinerja Keuangan: Panduan bagi Akademisi, Manajer, dan Investor untuk Menilai dan Menganalisis Bisnis dari Aspek Keuangan. Bandung: Alfabeta. 2011.

Kasmir. Analisis Laporan Keuangan. Jakarta: Rajawali Pers. 2008.

Mardiyanto, Handono. Inti Sari Manajemen Keuangan. Jakarta : PT Gramedia Widiasarana Indonesia. 2009.

Mulyadi. Akuntansi Manajemen : Konsep, Manfaat dan Rekayasa. Edisi Ketiga. Jakarta: Salemba Empat. 2001.

Munawir. Analisis Laporan Keuangan. Yogyakarta: Liberty. 2001.

--------. Analisis Laporan Keuangan. Yogyakarta: Liberty. 2010.

Putri, Sellyndah Primadani. Analisis Kinerja Keuangan PT. Mitra Adi Perkasa Sebelum dan Sesudah Akuisisi terhadap PT. Premiere Doughnut Indonesia. Jurnal Ilmiah Mahasiswa FEB Universitas Brawijaya, Vol. 3 No. 2.2015 .

Ridwan. Pengertian Penilaian Kinerja. Bandung: Alfabeta. 2008.

Riyanto, Bambang. Dasar-Dasar Pembelanjaan Perusahaan. Edisi Keempat. Yogyakarta: BPFE. 2001.

Sawir, Agnes. Analisa Kinerja Keuangan Dan Perencanaan Keuangan Perusahaan. Jakarta: PT Gramedia Pustaka Utama. 2001. 
Siagian, Sondang P. Manajemen Abad 21. Edisi Pertama. Jakarta: Bumi Aksara. 2000.

Srimindarti, Caecilia. Balanced Scorecard Sebagai Alternatif Untuk Mengukur Kinerja. Fokus Ekonomi. 2004.

Sugiyono. Metode Penelitian Pendidikan (Pendekatan Kuantitatif, Kualitatif dan $R \& D)$. Bandung: Penerbit Alfabeta. 2001.

Suparno. Akuntansi Manajemen. Yogyakarta: Liberty. 2005.

http://www.idx.com PT Bakrie Sumatera Plantations, Tbk 